\title{
Effects of reproductive mode on habitat-related differences in the population structure of eight Caribbean coral species
}

\author{
M. J. A. Vermeij ${ }^{1,2, *}$, P. R. Frade ${ }^{3,4,5}$, R. I. R. Jacinto ${ }^{3}$ A. O. Debrot ${ }^{2}$, R. P. M. Bak ${ }^{4,5}$ \\ ${ }^{1}$ Botany Department, University of Hawaii at Manoa, 3190 Maile Way, Honolulu, Hawaii 96822, USA \\ ${ }^{2}$ Caribbean Research and Management of Biodiversity (CARMABI), Piscaderabaai z/n, PO Box 2090, \\ Willemstad, Curaçao, Netherlands Antilles \\ ${ }^{3}$ Universidade de Lisboa, Faculdade de Ciências, Departamento de Biologia Animal, Campo Grande-Bloco C2, 1750 Lisboa, \\ Portugal \\ ${ }^{4}$ University of Amsterdam, Institute for Biodiversity and Ecosystem Dynamics (IBED), PO Box 94766, 1090 GT, Amsterdam, \\ The Netherlands \\ ${ }^{5}$ Netherlands Institute for Sea Research (NIOZ), PO Box 59, 1790 AB Den Burg, Texel, The Netherlands
}

\begin{abstract}
We compared the population structure of 8 common coral species in 2 contrasting habitats, the oceanic fringing reefs and the inland bays in Curaçao, Netherlands Antilles. Inland bays are only partially connected to the open ocean and are characterized by a natural suite of environmental factors thought to be detrimental to coral community development. Compared with the inland bays, coral cover and coral colony density were higher on the fringing reefs ( 7.6 and 11.7 times, respectively). Coral species that release gametes in the water column ('broadcast spawners') showed a much greater difference in population structure and density between inland bay and reef habitats compared to brooding species. Our results show that (1) 'marginal' habitats are not equally marginal to all species, (2) differential susceptibility to partial mortality plays a central role in restricting colony growth in inland bay habitats, and (3) most likely, post-settlement mortality rather than larval supply plays a key role in causing differences in habitat-scale size-frequency distributions. Broadcasting species reached larger mean and maximum colony size on the fringing reefs, whereas brooders did not show this pattern. The overrepresentation of large colonies in communities that had degraded in response to anthropogenic disturbance was not observed among coral populations in inland bays. Such characteristics deserve critical attention, as they can be used to distinguish between naturally and anthropogenically stressed Caribbean coral communities.
\end{abstract}

KEY WORDS: Scleractinia · Reproductive strategy · Population structure · Size-frequency distribution · Marginal habitats

\section{INTRODUCTION}

Coral communities are characterized by variation at various levels of organization: at the colony level, colonies can differ in the degree to which they are affected by partial mortality (Hughes 1984, Meesters et al. 1997); at the population level, variation can be expressed in terms of size-frequency distributions of coral colonies (e.g. Bak \& Meesters 1998, 1999,
Meesters et al. 2001, Vermeij \& Bak 2003a); and at the community level, there is variation in terms of species diversity (Van Duyl 1985). Variation at each level, roughly corresponding to an increasing spatial scale, is often non-random and has been used to provide information on interspecific differences (Bak \& Meesters 1998, 1999, Vermeij \& Bak 2003a), adaptation to environmental conditions (Meesters et al. 2001, Vermeij \& Bak 2003a) and as an indicator of reef decline (e.g. 
global change: Bak \& Meesters 1999, anthropogenic pollution: Meesters et al. 2001).

On the reefs of Curaçao, for example, reef communities in close proximity $(<1 \mathrm{~km})$ to a heavily urbanized area showed consistent differences in population structure when compared to nearby communities located up-current along the coast. On anthropogenically disturbed reefs, certain species had disappeared from the community, showed a different population structure (e.g. Colpophyllia natans and Diploria labyrinthiformis, Meesters et al. 2001), or were skewed in their population structures towards large individuals (Bak \& Meesters 1999). Furthermore, higher juvenile and partial mortality caused a concentration of colonies in medium size classes (shown by higher kurtosis, $\mathrm{g}_{2}$, and lower standard deviations for colony size) (Bak \& Meesters 1999, Meesters et al. 2001).

While there is some information on anthropogenically induced variation in coral community structure, studies on responses in coral community structure in naturally suboptimal environments are rare in the Caribbean. Overall it is known that coral community development depends on a large number of interacting environmental factors, e.g. light (Lesser et al. 2000), sedimentation (Nugues \& Roberts 2003, Schleyer \& Celliers 2003), food availability (Porter 1976), water movement (Sebens \& Johnson 1991) and effects of other reef inhabitants (Vermeij 2005, 2006). These factors can, alone or synergistically, determine a species' occurrence, depending on species-specific tolerance levels to these factors (Jackson 1991, Vermeij \& Bak 2003a).

Many of the factors that limit coral community development occur synergistically in the inland bays of Curaçao, Netherlands Antilles. In comparison to the fringing reefs bordering the open ocean, inland bays are only partially connected to the open ocean (Fig. 1). They are historically characterized by factors that are thought to be detrimental to coral community development, such as elevated temperatures, higher salinity, increased nutrient and sedimentation levels, reduced water flow due to low tidal fluctuations, and a large reduction in water transparency (Wagenaar Hummelinck 1977, Van Duyl 1985, Debrot et al. 1998, Bak \& Meesters 2003). Consequently, the inland bays are expected to be a less suitable environment for coral community development (often notionally referred to as a 'marginal habitat') than the nearby fringing reefs that directly border oceanic water (Van Duyl 1985, Debrot et al. 1998, Perry \& Larcombe 2003). On Curaçao, numerous inland bays are structural components of the present-day reef ecosystem that were created when old riverbeds flooded during the Holocene sea level rises $(<12000$ yr ago) and have been available for coral community development ever since (De Buisonjé 1974, Klosowska 2003). They are located

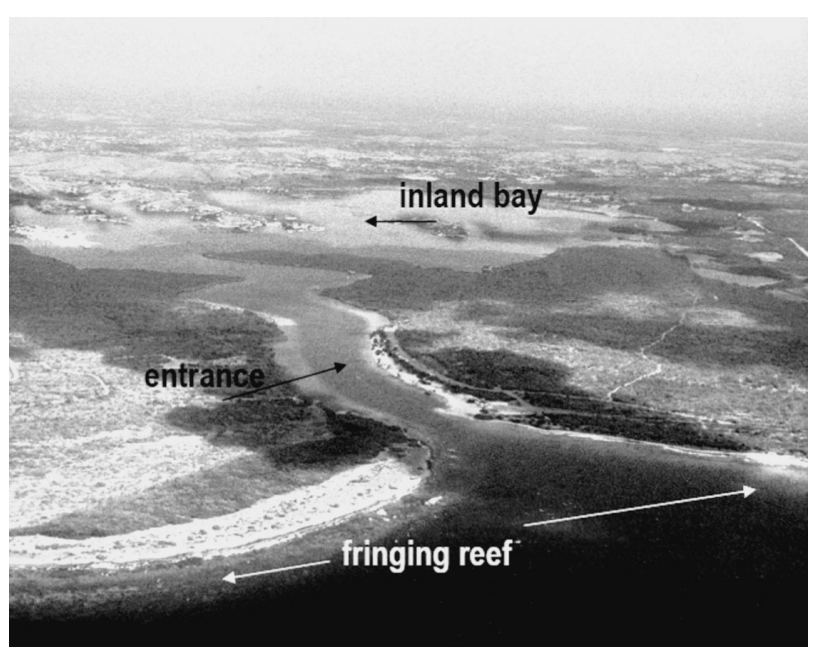

Fig. 1. Aerial overview of Spaanse Water, a typical inland bay on Curaçao, Netherlands Antilles, and one used in this study. The fringing reef, the entrance to the inland bay and the inland bay itself can be seen from the bottom upwards.

Photo: R.P.M.B.

away from the urbanized area on the island and thus represent a suite of natural, albeit less optimal, environmental conditions for coral development compared with the nearby $(<1 \mathrm{~km})$ fringing reef communities.

Caribbean coral species with external and internal fertilization (broadcast spawners and brooders, respectively) are expected to respond differently to the variable environmental conditions that exist on fringing reefs and inland bays due to general differences in life-history strategies associated with each reproductive mode (Szmant 1986, Harrison \& Wallace 1990, Hughes \& Connell 1999). In general, broadcast species are predominant in stable, benign environments (Szmant 1986), whereas brooding species dominate in areas where environmental conditions vary through time, such as the inland bays observed in this study (Szmant 1986). Characteristics that distinguish brooding from spawning Caribbean coral species include the production of larger planulae over longer periods of time (Szmant 1986), a short planktonic phase (Smith 1992) and fast growth rates after settlement (Rylaarsdam 1983). These characteristics could explain the higher success of brooding species under temporally variable conditions or on degraded reefs (Knowlton 2001).

By providing detailed descriptions of coral communities in 4 sites for each habitat type (i.e. fringing reef and inland bay), we aim to determine (1) which community, population or colony characteristics can be used to define communities typical for either habitat type, and (2) whether species with different reproductive modes show similar differences between the 2 habitat types. We will then discuss differences in coral 
community structure under natural marginal conditions (i.e. the inland bays) and compare these observations to differences described for anthropogenically disturbed reefs on the same island (Bak \& Meesters 1999, Meesters et al. 2001).

\section{MATERIALS AND METHODS}

Study sites. Data were collected at Curaçao $\left(12^{\circ} 02^{\prime}-\right.$ $12^{\circ} 23^{\prime} \mathrm{N} ; 68^{\circ} 44^{\prime}-69^{\circ} 10^{\prime} \mathrm{W}$ ), Netherlands Antilles (Fig. 2) in 2002 and 2003. Almost the entire island is surrounded by a continuous fringing reef (Van Duyl 1985) and along the coast, large inland bays are connected to the ocean through narrow entrances ( $<50 \mathrm{~m}$ wide). Coral population structure was quantified in 4 inland bays (IBs), i.e. Piscaderabaai (IB1), Spaanse Water (IB2), Santa Martha Baai (IB3) and Playa Grandi (IB4), and at 4 fringing reef sites (RSs) directly bordering oceanic waters along the leeward side of the island, Carmabi Buoy Zero (RS1), Punta Caballero (RS2), Cornelis (RS3) and Seaquarium (RS4) (Fig. 2).

The benthic substrate in the middle of the inland bays generally consists of mud or sand, shells, rubble, small rocks, and seagrass beds in some areas. The inland bays also have patchily distributed hard substratum, which consists of limestone outcroppings rising from the bottom. In comparison to fringing reefs,

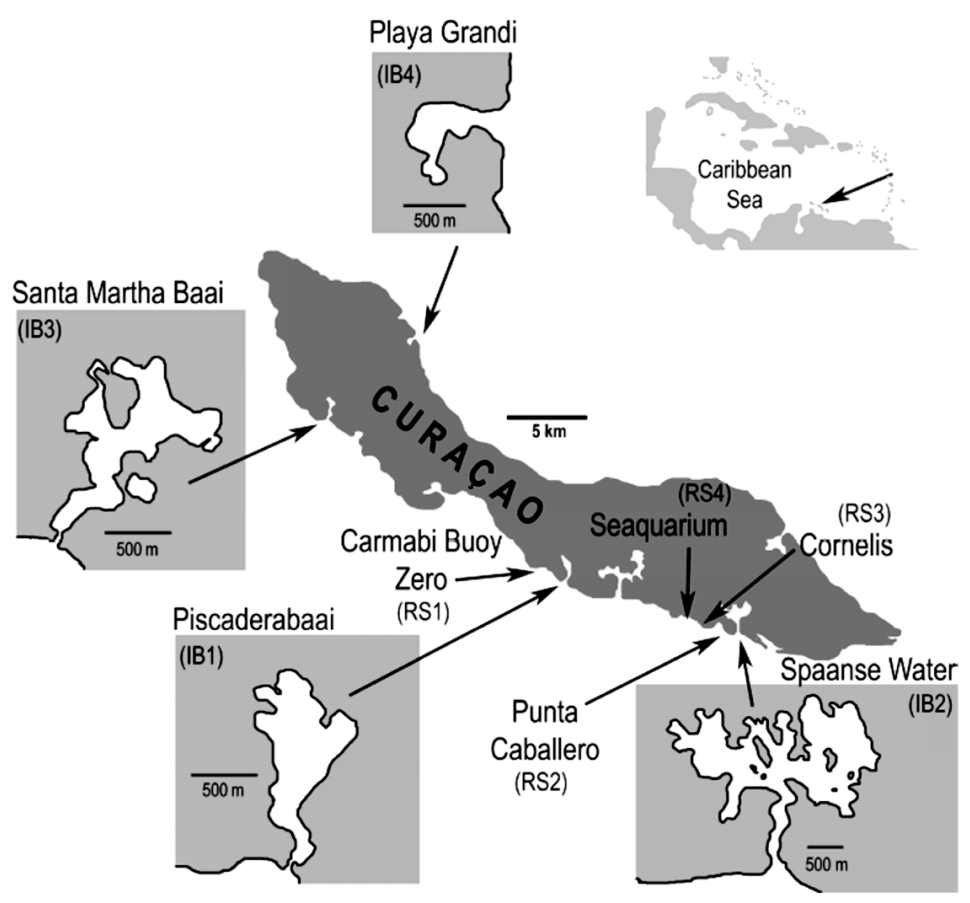

Fig. 2. Location of Curaçao and sampling sites. Inland bays: Piscadera Baai (IB1), Spaanse Water (IB2), Santa Martha Baai (IB3) and Playa Grandi (IB4); reef sites: Carmabi Buoy Zero (RS1), Punta Caballero (RS2), Cornelis (RS3) and Seaquarium (RS4) inland bays are characterized by elevated temperatures, higher salinities, increased nutrient and sedimentation levels due to terrestrial run-off, reduced water flow and reduced water transparency (Wagenaar Hummelinck 1977, Van Duyl 1985, Debrot et al. 1998).

Study species. Included in our surveys were 8 coral species ( 5 broadcast-spawning and 3 brooding species) that are naturally dominant on both the reef flat as well as the reef slope ( 3 to $34 \mathrm{~m}$ depth) of the fringing reefs in Curaçao (Van Duyl 1985). The 5 broadcastspawning species were: (1) Montastraea annularis s.s. (Ellis \& Solander, 1786), (2) Diploria labyrinthiformis (Linnaeus, 1758), (3) D. strigosa (Dana, 1846), (4) Colpophyllia natans (Müller, 1775) and (5) Siderastrea siderea (Ellis \& Solander, 1786). These species can reach large colony size (Meesters et al. 2001) and spawn gametes once or twice per year (De Graaf et al. 1999). The 3 brooding species included were: (1) Siderastrea radians (Pallas, 1766), (2) Porites astreoides Lamarck, 1816 and (3) Favia fragum (Esper, 1795). These brooding species release planulae rather than gametes and their reproductive periods are considerably longer compared with the spawning events of broadcast species (Szmant-Froelich et al. 1985, Soong 1991, McGuire 1998, Vermeij 2005). S. radians and F. fragum are considered as typical shallow water species with a high tolerance to environmental conditions that characterize inland bays (Roos 1970). Other coral species were not abundant enough in either habitat type to provide reliable comparisons between the 2 habitat types and therefore they were not included in this study.

Coral community surveys. All coral colonies were quantified in $1 \mathrm{~m}$-wide belt transects positioned along isobaths parallel to shore at depths where the coral species considered in this study were most abundant, i.e. at 5 to $6 \mathrm{~m}$ depth on the reef and 0.5 to $2.5 \mathrm{~m}$ depth in the inland bays. We thus assumed that surveying coral communities at depths where they were most abundant in each habitat type (rather than at the same depth) allowed for a more standardized comparison between coral communities in each habitat type. Transects were initially $20 \mathrm{~m}$ long but were extended to increase sample size for all coral species to $>200$ colonies per site. Since corals communities occurred as isolated patches within the bays, a new transect was started at another patch location if the initial location did not contain >200 colonies of a particular species. Ultimately, the maximum number of 
colonies at a site was limited by the total number colonies present. Densities were recorded by subdividing the transect area in $1 \mathrm{~m}^{2}$ sub-plots within which all colonies were counted.

Coral colony definition and size measurements. A colony was defined as the total surface of living tissue, connected through a shared skeleton and assumed to have originated from one zygote. When a colony suffers partial mortality, the living surfaces can exist as separate units, but when these disconnected surfaces formed one discernable entity, the separate parts were summed and used as one colony size measurement. If a colony suffered partial mortality, then the area of the coral skeleton without living tissue was additionally quantified so that the degree of partial mortality could be expressed as:

Partial mortality $\mathrm{in}_{(\mathrm{in})}=$ $\left[\right.$ total $\left._{\text {dead surface }}\right] /\left[\right.$ total $_{\text {dead surface }}+$ total $\left._{\text {living surface }}\right] \times 100$

All surfaces were measured by overlying the colony with flexible transparent sheets with 4, 2, 1, 0.25 and $0.0625 \mathrm{~cm}^{2}$ grids (grid choice was dependent on colony size) and then counting the number of squares covering the surface of the colony. Great care was taken to find all coral colonies in each transect and the smallest colonies included in this study measured $0.06 \mathrm{~cm}^{2}$.

Size-frequency descriptors. Skewness $\left(g_{1}\right)$ is an indicator of a distribution's shape around the mean. A positive value indicates a long right tail; a negative value, a long left tail. This corresponds to a relative overrepresentation of small and/or an underrepresentation of large colonies (i.e. $g_{1}>0$ ) or vice versa (i.e. $g_{1}<0$ ). After $\log$ transformation of size data to increase analytic resolution in smaller size classes (for details see: Bak \& Meesters 1998, Vermeij \& Bak 2003b), the skewness of a coral population is a good indicator of the fraction of small colonies relative to larger colonies within the population (Bak \& Meesters 1998, Vermeij \& Bak 2003a). The coefficient of variation (CV) given by the sample standard deviation divided by the sample mean is a standard measure of variation in populations. Data are also log-transformed before calculating $\mathrm{CV}$.

$g_{1}$ and $C V$ were calculated for each species per site together with standard descriptive statistics, such as mean colony size. The $+95 \%$ percentile of the mean was used as an indicator of maximum colony size for each species $\times$ site combination (sensu Soong 1993). If $<20$ colonies were found within a site, no sizefrequency statistics were calculated.

Statistics. Similarity in size-frequency distribution of 2 coral populations was calculated using the Spearman rank-correlation coefficient after dividing all colonies over 20 size classes based on a logarithmic scale: 0.06 , $0.13,0.25,0.50,1.00,2.00,4.00, \ldots 32768 \mathrm{~cm}^{2}$. The resulting similarity measures were grouped by reproductive mode, species or habitat type (or combinations thereof) to provide an averaged estimate of the overall similarity within each grouping (see: Meesters et al. 2001 for further details). Site and species-specific differences in colony size distribution and density were compared using ANOVA after log-transforming the size data to reduce non-normality and heteroscedasticity. Residuals were graphically examined to test assumptions of the analyses. Differences in the occurrence of partial mortality (in $\mathrm{cm}^{2}$ ) are compared between species and sites using a separate-slopes ANCOVA using log-transformed colony size as a covariable. All analyses were followed by multiple comparison tests (Tukey's honestly significant difference, HSD, test) to indicate significant differences between group means.

\section{RESULTS}

\section{General patterns in community composition}

Coral cover (all species combined) was 7.6 times higher on the reef than inside the inland bays (Fig. 3). Brooding species contributed 35.9\% (SD 43.2; $\mathrm{n}=4$ ) to total cover in inland bays and $2.3 \%(\mathrm{SD} 0.9 ; \mathrm{n}=4$ ) to cover on the reef. Numerically, brooding species contributed on average $66.5 \%($ SD $24.4 ; \mathrm{n}=4)$ to the total number of colonies in inland bays and $34.2 \%$ (SD 16.0; $\mathrm{n}=4$ ) on the reef (Table 1). Brooding species never dominated any of the sites in terms of cover or number except in Playa Grandi (IB4) where Siderastera radians was the only species present.

\section{Density}

Species densities varied among sites and between species (Tables $1 \& 2$ ). The broadcasting species Montastraea annularis, Colpophyllia natans and Diploria labyrinthiformis had significantly lower densities in inland bays and were solely responsible for overall differences in density between the 2 habitats and between species (Tukey post-hoc test; $p<0.05$ ). Differences in densities between inland bays and reef sites were small for the brooding species Favia fragum and Siderastrea radians (Table 1). The non-significant species $\times$ habitat interaction indicated that site-specific (rather than habitat-specific) responses in density were rare and all species show an overall, rather than a species-specific, reduction in density inside the inland bays. Broadcast spawners and brooders are both more abundant on the reef: $17.4(\mathrm{SD} 20.7 ; \mathrm{n}=5)$ and 2.2 (SD 2.2; $\mathrm{n}=3$ ) times more abundant, respectively. 


\section{Size-frequency statistics}

Populations of both broadcasting and brooding species showed consistent structure among sites within each habitat type. Overall similarity in population structure, i.e. between all 8 sites, was higher for brooding species (82 to $91 \%$ ) than broadcasting species (33 to $60 \%$; ANOVA, $\left.F_{1,7}=19.00, \mathrm{p}<0.01\right)$. On the reef, similarity in species size-frequency distributions ranged between 58 and $83 \%$ for broadcasting species, and between 86 and $98 \%$ for brooding species. In inland bays the ranges for broadcasting and brooding species were 21 to $84 \%$ and 72 to $96 \%$, respectively, indicating greater dissimilarity in population structure in this habitat type. Only 2 out of 8 species showed significant differences in population structure between the 2 habitats: Colpophyllia natans and Siderastrea siderea.

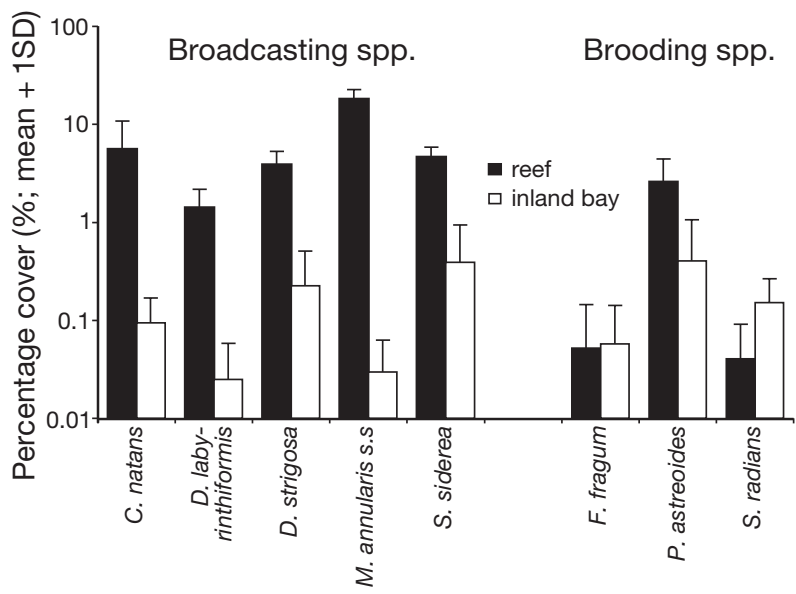

Fig. 3. Percentage cover of all coral species considered in this study for the 2 habitat types. Note that the $y$-axis is logarithmic. Full species names given in Table 1

Table 1. Coral species. Overview of colony density and size-frequency descriptors. Inland bays: Piscadera Bay (IB1), Spaanse Water (IB2), Santa Martha Bay (IB3) and Playa Grandi (IB4); reef sites: Carmabi Buoy Zero (RS1), Punta Caballero (RS2), Cornelis (RS3) and Seaquarium (RS4). N: number of colonies sampled; mean density: average cover of species; mean colony size: average size of colonies per species per site. 95\%: 95\%-confidence interval for average colony size, which is indicative of the maximum size a species can obtain within a site. 'Tot Surf': total living surface area of species at site. Coefficient of variation (CV) and skewness $\left(\mathrm{g}_{1}\right)$ are calculated based on log-transformed size data

\begin{tabular}{|c|c|c|c|c|c|c|c|c|c|}
\hline \multirow[t]{3}{*}{ Site } & \multirow[t]{3}{*}{$\mathrm{N}$} & \multirow{2}{*}{\multicolumn{2}{|c|}{ Density $\left(\mathrm{nm}^{-2}\right)$}} & \multicolumn{6}{|c|}{ Colony size $\left(\mathrm{cm}^{2}\right)-$} \\
\hline & & & & \multicolumn{4}{|c|}{ Non-transformed } & \multicolumn{2}{|c|}{ ln-transformed } \\
\hline & & Mean & $\mathrm{SD}$ & Mean & SEM & $95 \%$ & Tot Surf & $\mathrm{CV}$ & $g_{1}$ \\
\hline \multicolumn{10}{|c|}{ Broadcast spawning species } \\
\hline \multicolumn{10}{|c|}{ Colpophyllia natans } \\
\hline RS1 & 111 & 0.10 & 0.13 & 1584.7 & 324.5 & 7387.8 & $1.76 \times 10^{5}$ & 0.34 & -0.41 \\
\hline RS2 & 107 & 0.20 & 0.17 & 593.2 & 95.2 & 1944.2 & $6.35 \times 10^{4}$ & 0.32 & -0.56 \\
\hline RS3 & 104 & 0.42 & 0.38 & 2399.8 & 6235.3 & 3612.4 & $2.50 \times 10^{5}$ & 0.42 & -0.03 \\
\hline RS4 & 109 & 0.44 & 0.37 & 1709.4 & 382.9 & 2468.4 & $1.86 \times 10^{5}$ & 0.45 & 0.09 \\
\hline IB1 & 5 & 0.01 & 0.02 & 2793.8 & 1233.4 & 6262.5 & $1.40 \times 10^{4}$ & 0.16 & 0.20 \\
\hline IB2 & 34 & 0.01 & 0.03 & 976.1 & 396.9 & 5384.8 & $3.32 \times 10^{4}$ & 0.29 & 0.13 \\
\hline IB3 & 50 & 0.09 & 0.11 & 143.3 & 54.9 & 707.8 & $7.16 \times 10^{3}$ & 0.52 & 0.52 \\
\hline IB4 & 0 & 0.00 & 0.00 & - & - & - & - & - & - \\
\hline \multicolumn{10}{|c|}{ Diploria labyrinthiformis } \\
\hline RS1 & 252 & 0.42 & 0.31 & 438.8 & 54.2 & 2300.0 & $1.11 \times 10^{5}$ & 0.44 & -0.08 \\
\hline RS2 & 106 & 0.22 & 0.14 & 183.0 & 29.0 & 715.8 & $1.94 \times 10^{4}$ & 0.43 & -0.36 \\
\hline RS3 & 103 & 0.43 & 0.40 & 864.0 & 233.9 & 1327.9 & $8.90 \times 10^{4}$ & 0.54 & 0.67 \\
\hline RS4 & 55 & 0.17 & 0.27 & 1232.7 & 310.7 & 1855.7 & $6.78 \times 10^{4}$ & 0.42 & -0.24 \\
\hline IB1 & 4 & 0.01 & 0.04 & 219.0 & 60.4 & 333.0 & $8.76 \times 10^{2}$ & 0.16 & -1.67 \\
\hline IB2 & 70 & 0.01 & 0.02 & 120.1 & 27.9 & 506.0 & $8.41 \times 10^{3}$ & 0.53 & 0.23 \\
\hline IB3 & 68 & 0.06 & 0.09 & 124.1 & 20.9 & 520.3 & $8.44 \times 10^{3}$ & 0.39 & -0.20 \\
\hline IB4 & 0 & 0.00 & 0.00 & - & - & - & - & - & - \\
\hline \multicolumn{10}{|c|}{ Diploria strigosa } \\
\hline RS1 & 273 & 1.09 & 1.14 & 446.3 & 47.8 & 2255.8 & $1.22 \times 10^{5}$ & 0.47 & -0.10 \\
\hline RS2 & 304 & 1.52 & 0.63 & 292.2 & 39.4 & 1240.6 & $8.88 \times 10^{4}$ & 0.42 & -0.18 \\
\hline RS3 & 57 & 0.23 & 0.30 & 380.0 & 110.2 & 600.7 & $2.17 \times 10^{4}$ & 0.50 & 0.27 \\
\hline RS4 & 116 & 0.46 & 0.37 & 946.7 & 154.9 & 1253.5 & $1.10 \times 10^{5}$ & 0.38 & -0.08 \\
\hline IB1 & 114 & 0.10 & 0.09 & 126.7 & 35.8 & 639.0 & $1.44 \times 10^{4}$ & 0.60 & 0.54 \\
\hline IB2 & 258 & 0.29 & 0.37 & 219.1 & 67.7 & 665.9 & $5.65 \times 10^{4}$ & 0.45 & -0.12 \\
\hline IB3 & 254 & 0.37 & 0.25 & 35.2 & 4.4 & 162.8 & $8.95 \times 10^{3}$ & 0.50 & 0.46 \\
\hline IB4 & 0 & 0.00 & 0.00 & - & - & - & - & - & - \\
\hline
\end{tabular}


Table 1 (continued)

\begin{tabular}{|c|c|c|c|c|c|c|c|c|c|}
\hline \multirow[t]{3}{*}{ Site } & \multirow[t]{3}{*}{$\mathrm{N}$} & \multirow{2}{*}{\multicolumn{2}{|c|}{ Density $\left(\mathrm{nm}^{-2}\right)$}} & \multicolumn{6}{|c|}{ - Colony size $\left(\mathrm{cm}^{2}\right)$} \\
\hline & & & & \multirow[b]{2}{*}{ Mean } & \multicolumn{2}{|c|}{ Non-transformed } & \multirow[b]{2}{*}{ Tot Surf } & \multicolumn{2}{|c|}{ ln-transformed } \\
\hline & & Mean & SD & & SEM & $95 \%$ & & $\mathrm{CV}$ & $g_{1}$ \\
\hline \multicolumn{10}{|c|}{ Montastraea annularis } \\
\hline RS1 & 96 & 0.96 & 0.81 & 1464.1 & 597.2 & 3976.5 & $1.41 \times 10^{5}$ & 0.30 & -0.33 \\
\hline $\mathrm{RS} 2$ & 115 & 0.86 & 0.66 & 1713.0 & 368.9 & 5464.4 & $1.97 \times 10^{5}$ & 0.28 & -0.42 \\
\hline RS3 & 117 & 1.06 & 0.76 & 4238.3 & 414.1 & 5058.4 & $4.96 \times 10^{5}$ & 0.21 & -1.00 \\
\hline RS4 & 103 & 0.41 & 0.32 & 5502.7 & 841.2 & 7171.3 & $5.67 \times 10^{5}$ & 0.23 & -0.53 \\
\hline IB1 & 13 & 0.02 & 0.06 & 321.7 & 174.4 & 2263.1 & $4.18 \times 10^{3}$ & 0.46 & 0.06 \\
\hline IB2 & 65 & 0.01 & 0.04 & 272.6 & 52.3 & 971.8 & $1.77 \times 10^{4}$ & 0.30 & -0.13 \\
\hline IB3 & 25 & 0.03 & 0.05 & 44.3 & 17.2 & 179.6 & $1.11 \times 10^{3}$ & 0.35 & 1.13 \\
\hline IB4 & 0 & 0.00 & 0.00 & - & - & - & - & - & - \\
\hline \multicolumn{10}{|c|}{ Siderastrea siderea } \\
\hline RS1 & 263 & 0.45 & 0.39 & 745.8 & 119.3 & 3507.7 & $1.96 \times 10^{5}$ & 0.61 & 0.28 \\
\hline $\mathrm{RS} 2$ & 265 & 1.13 & 0.59 & 505.7 & 83.5 & 2399.3 & $1.34 \times 10^{5}$ & 0.55 & 0.13 \\
\hline RS3 & 72 & 0.29 & 0.30 & 2955.5 & 576.9 & 4105.9 & $2.13 \times 10^{5}$ & 0.46 & -0.64 \\
\hline RS4 & 101 & 0.46 & 0.42 & 1232.5 & 243.9 & 1716.4 & $1.24 \times 10^{5}$ & 0.49 & -0.44 \\
\hline IB1 & 295 & 0.41 & 0.43 & 72.9 & 8.5 & 408.2 & $2.15 \times 10^{4}$ & 0.65 & 0.16 \\
\hline IB2 & 259 & 0.73 & 0.49 & 163.3 & 28.3 & 622.2 & $4.23 \times 10^{4}$ & 0.43 & 0.25 \\
\hline IB3 & 117 & 0.11 & 0.11 & 51.2 & 7.1 & 274.7 & $5.99 \times 10^{3}$ & 0.55 & 0.08 \\
\hline IB4 & 0 & 0.00 & 0.00 & - & - & - & - & - & - \\
\hline \multicolumn{10}{|c|}{ Brooding species } \\
\hline \multicolumn{10}{|c|}{ Favia fragum } \\
\hline RS1 & 259 & 0.25 & 0.45 & 6.7 & 0.5 & 21.2 & $1.73 \times 10^{3}$ & 0.54 & 0.11 \\
\hline $\mathrm{RS} 2$ & 277 & 4.95 & 5.45 & 3.9 & 0.3 & 14.6 & $1.07 \times 10^{3}$ & 0.62 & 0.61 \\
\hline RS3 & 0 & 0.00 & 0.00 & - & - & - & - & - & - \\
\hline RS4 & 0 & 0.00 & 0.00 & - & - & - & - & - & - \\
\hline IB1 & 0 & 0.00 & 0.00 & - & - & - & - & - & - \\
\hline IB2 & 301 & 0.91 & 1.71 & 5.6 & 0.5 & 18.6 & $1.70 \times 10^{3}$ & 0.62 & 0.66 \\
\hline IB3 & 451 & 3.76 & 2.05 & 4.7 & 0.3 & 13.0 & $2.14 \times 10^{3}$ & 0.47 & 0.16 \\
\hline IB4 & 0 & 0.00 & 0.00 & - & - & - & - & - & - \\
\hline \multicolumn{10}{|c|}{ Porites astreoides } \\
\hline RS1 & 281 & 1.41 & 1.55 & 62.0 & 5.6 & 273.2 & $1.74 \times 10^{4}$ & 0.52 & -0.10 \\
\hline $\mathrm{RS} 2$ & 307 & 6.14 & 1.62 & 78.1 & 6.5 & 257.7 & $2.40 \times 10^{4}$ & 0.51 & -0.31 \\
\hline RS3 & 124 & 1.83 & 1.21 & 195.7 & 33.6 & 262.3 & $2.43 \times 10^{4}$ & 0.54 & -0.06 \\
\hline RS4 & 116 & 0.86 & 0.62 & 158.9 & 25.8 & 210.1 & $1.84 \times 10^{4}$ & 0.40 & -0.44 \\
\hline IB1 & 43 & 0.04 & 0.06 & 122.8 & 21.4 & 395.4 & $5.28 \times 10^{3}$ & 0.44 & -0.57 \\
\hline IB2 & 263 & 1.43 & 0.60 & 97.2 & $\begin{array}{r}21.7 \\
5.8\end{array}$ & 292.8 & $2.56 \times 10^{4}$ & 0.28 & -0.82 \\
\hline IB3 & 258 & 0.70 & 0.36 & 25.5 & 5.5 & 117.4 & $6.58 \times 10^{3}$ & 0.62 & 1.14 \\
\hline IB4 & 0 & 0.00 & 0.00 & - & - & - & - & - & - \\
\hline \multicolumn{10}{|c|}{ Siderastrea radians } \\
\hline RS1 & 358 & 2.98 & 1.71 & 2.0 & 0.2 & 8.2 & $7.03 \times 10^{2}$ & 0.99 & 1.15 \\
\hline $\mathrm{RS} 2$ & 258 & 4.82 & 2.73 & 2.2 & 0.2 & 8.0 & $5.56 \times 10^{2}$ & 0.70 & 1.00 \\
\hline RS3 & 0 & 0.00 & 0.00 & - & - & - & - & - & - \\
\hline RS4 & 0 & 0.00 & 0.00 & - & - & - & - & - & - \\
\hline IB1 & 279 & 5.58 & 3.28 & 5.6 & 0.5 & 21.0 & $1.57 \times 10^{3}$ & 0.66 & 0.42 \\
\hline IB2 & 334 & 1.67 & 2.03 & 6.4 & 0.4 & 21.9 & $2.14 \times 10^{3}$ & 0.51 & 0.13 \\
\hline IB3 & 300 & 0.80 & 1.76 & 5.8 & 0.5 & 24.0 & $1.75 \times 10^{3}$ & 0.72 & 0.43 \\
\hline IB4 & 333 & 1.67 & 0.47 & 8.3 & 0.6 & 32.0 & $2.75 \times 10^{3}$ & 0.60 & 0.37 \\
\hline
\end{tabular}

Mean colony size differed between species and between habitats (Tables 1 \& 2). Differences in mean colony size in response to reef and inland bay habitat were species-specific (significant species $\times$ habitat interaction, Table 2; Siderastrea radians and Favia fragum-being absent at, respectively, 2 and 4 siteswere excluded from the analysis). Post-hoc compari- sons revealed that the broadcasting species (Colpophyllia natans, Montastraea annularis, S. siderea, Diploria labyrinthiformis and D. strigosa) reached larger mean and maximum colony size (indicated by the $95 \%$-confidence interval in Table 1; sensu Soong 1993) on the reef than those recorded at inland bay sites, whereas brooding species showed either the inverse 
relationship (S. radians) or no pattern at all (Porites astreoides , F. fragum).

The distinction in size-frequency characteristics between broadcasting and brooding species is not limited to colony size (Fig. 4). Inland bay populations of Colpophyllia natans and Montastraea annularis have higher $g_{1}$ values (Table 1), indicating that large colonies were underrepresented. Inland bay populations of M. annularis and Siderastrea siderea are characterized by lower variation in colony size, indicated by lower standard errors (SEM, Table 1).

This response in population structure, i.e. an underrepresentation of large colonies and smaller mean colony size resulting in overall lower size variation, was observed in all broadcasting species, but due to high natural variation within each habitat, the response was only statistically significant for Montastraea annularis, Siderastrea siderea and Colpophyllia natans (Kruskal-Wallis 1-way ANOVA $i \mathrm{p}<0.05$ ). These patterns were not observed for any of the brooding species in this study.

\section{Partial mortality}

The proportion of a colony affected by partial mortality increased with increasing colony size in all species, although the relationship between colony size and the level of partial mortality differed among species. Partial mortality differed significantly between species and habitat type (Fig. 4, Table 3). Three of our 8 species -2 broadcasting and 1 brooding species showed significantly higher partial mortality inside the inland bays (Tukey post-hoc test; $\mathrm{p}<0.05$ ): Montastraea annularis (16\% higher), Siderastrea siderea (8\% higher) and $S$. radians (7\% higher). IB4, harboring a coral community consisting of $S$. radians only, showed the highest level of partial mortality of all sites, $32 \%$ on average per colony.

\section{DISCUSSION}

Various studies have described coral communities outside their traditionally assumed environmental tolerance (e.g. Meesters et al. 2002, Bak \& Meesters 2003, Perry \& Larcombe 2003). The inland bays on Curaçao harbor coral communities facing a multitude of natural factors that can limit their development in terms of growth and survival. Therefore comparing the structure of these coral communities with those that occur on nearby fringing reefs, which lack most of the detrimental factors typical of inland bays, will yield information on the differences in coral community structure that characterize communities in 'marginal environ-
Table 2. Coral species. ANOVA results for differences in density and mean colony size among habitats and between species. ns: not significant

\begin{tabular}{|lccccc|}
\hline & SS & df & MS & $F$ & $p$ \\
\hline Density & & & & & \\
Species & 4.58 & 7 & 0.65 & 3.22 & $<0.01$ \\
Habitat & 1.02 & 1 & 1.02 & 5.00 & $<0.05$ \\
Species $\times$ Habitat & 1.62 & 7 & 0.23 & 1.14 & $\mathrm{~ns}$ \\
Error & 9.77 & 48 & 0.20 & & \\
Mean colony size & & & & & \\
Species & $1.92 \times 10^{7}$ & 7 & $2.75 \times 10^{6}$ & 5 & $<0.001$ \\
Habitat & $5.76 \times 10^{6}$ & 1 & $5.76 \times 10^{6}$ & 10 & $<0.001$ \\
Species $\times$ Habitat & $1.22 \times 10^{7}$ & 7 & $1.74 \times 10^{6}$ & 3 & $<0.001$ \\
Error & $2.16 \times 10^{7}$ & 36 & $6.00 \times 10^{5}$ & & \\
\hline
\end{tabular}

ments' (here: inland bays). We can compare these observed differences in coral community structure in response to naturally suboptimal habitats with those that have been described for coral communities that are under anthropogenic pressure on the same island (described in Bak \& Meesters 1999, Meesters et al. 2001). These studies showed that anthropogenically induced degradation of coral communities caused predictable differences in species population structure when compared with undisturbed control sites. The inland bay coral communities surveyed in this study do not represent such anthropogenically stressed reefs and are only similar to them in the sense that they both represent suboptimal environments for coral community development. Distinctive characteristics of the population structure of coral species that occur inside these inland bays differ from those that occur on degraded reefs. The main characteristic of populations on degraded reefs is a higher negative skewness of size-frequency distributions, which indicates that the majority of coral colonies occur in the larger size classes. This characteristic, indicative of higher mortality in the smallest size classes relative to unaffected control sites (Meesters et al. 2001), is absent in inland bay coral populations, where juveniles were still present, albeit in lower densities compared with the reef sites. The smaller mean colony size, particularly for broadcasting species, further indicates that populations in inland bays are not characterized by an overrepresentation of large colonies. Combined, these observations suggest that coral communities that have become stressed relatively recently (e.g. those studied by Meesters et al. 2001) have a population structure distinguishable from communities that have occurred under natural suboptimal conditions for many generations.

The difference in population structure between the reef and inland bay habitats was minimal for the brooding species, especially for Favia fragum and 


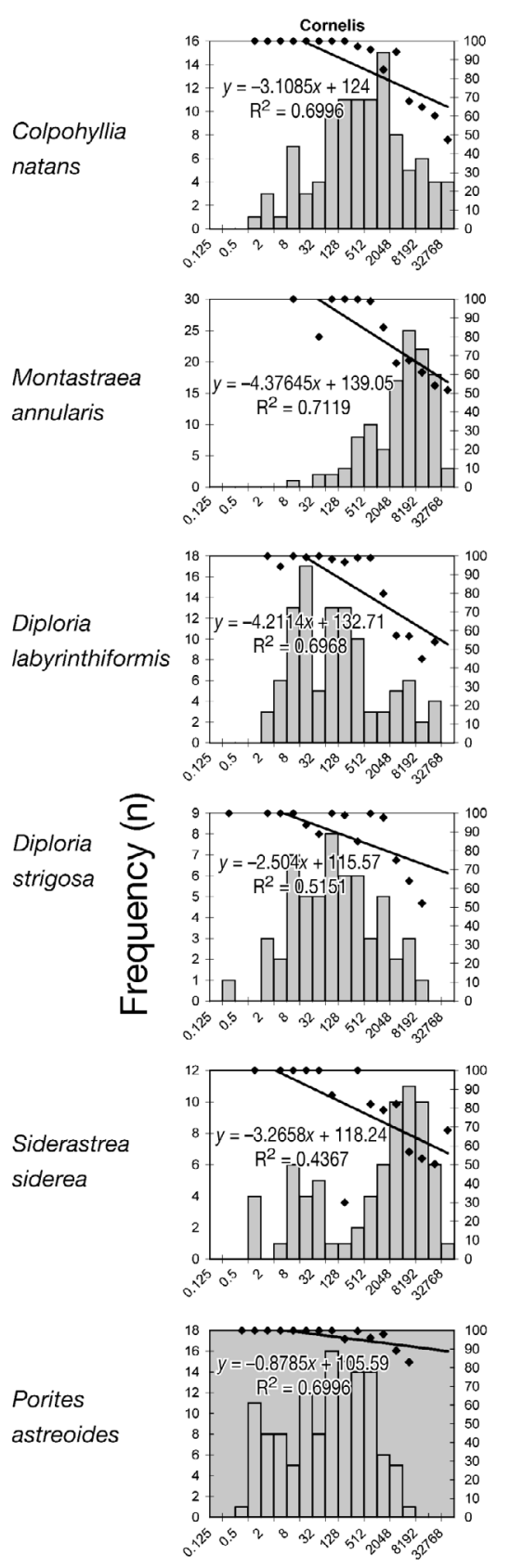

Fig. 4. Coral species from (A) reef sites or (B) inland bay sites. Size-frequency distributions for all species and all sites (log-transformed colony size, note scale on $x$-axis). Lines indicate linear regression lines for partial mortality (the mean percentage of living tissue per size class is indicated by $\bullet$ ). Colony size is defined as total surface of living tissue and dead surface forming one structural entity that can be assumed to have originated from one zygote. White background: broadcast spawner; grey background: brooding species

\section{Reef sites}
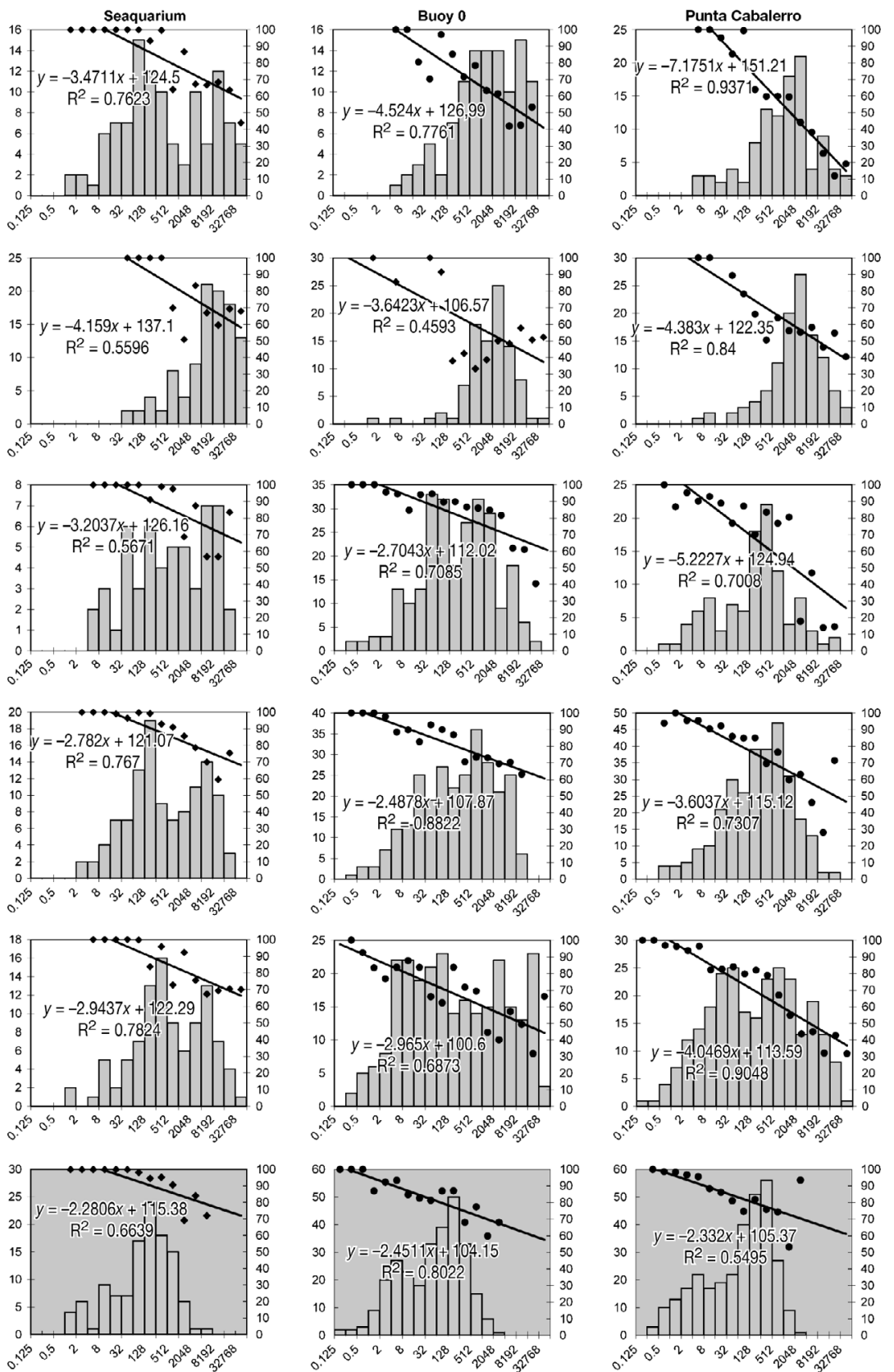


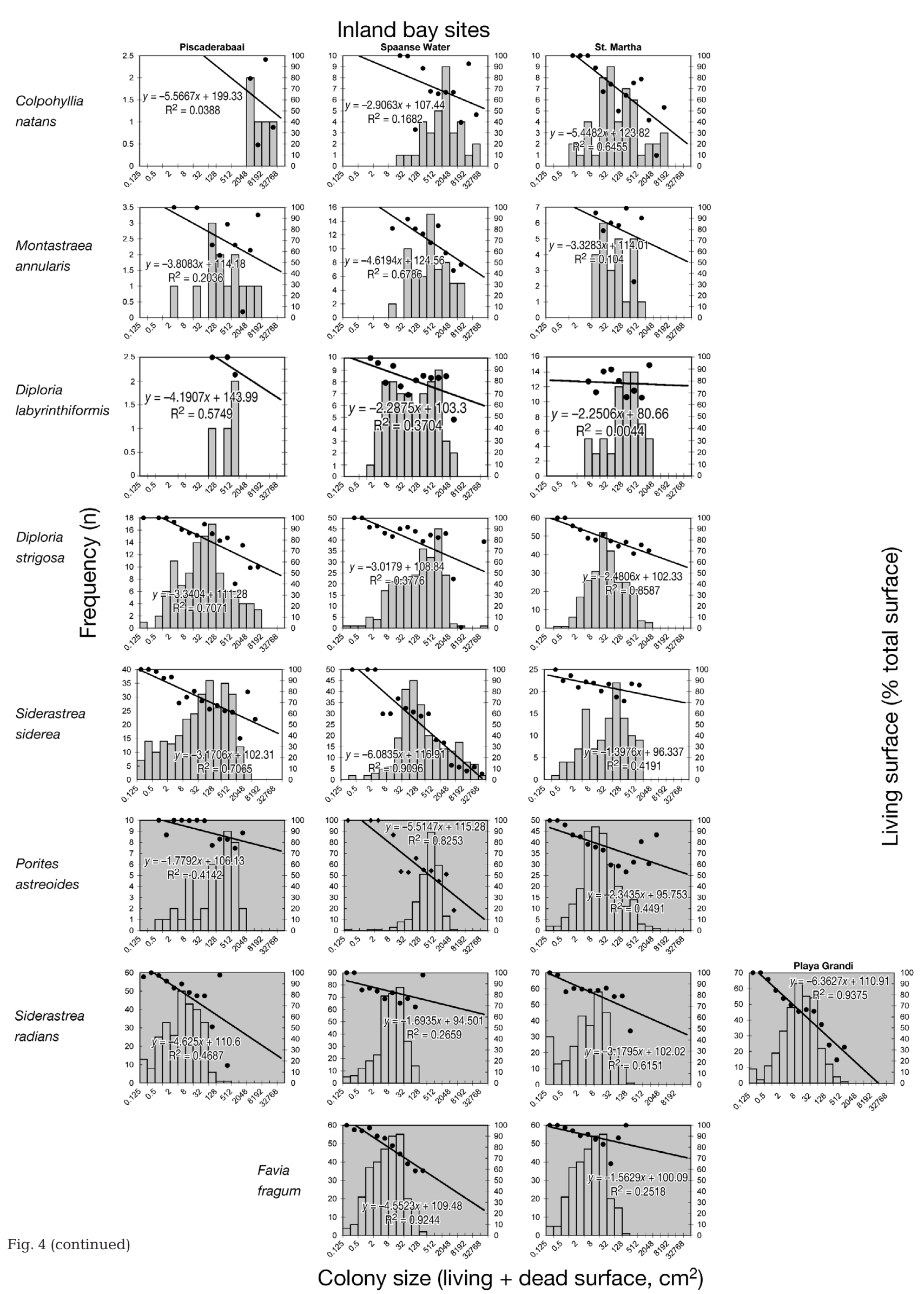


Table 3. Coral species. Comparisons in the prevalence of partial mortality between sites and species (separate slopes ANCOVA) using log-transformed colony size as a covariate. Inland bays IB1 and IB4 are excluded due to their overall low coral abundance

\begin{tabular}{|ccccrc|}
\hline & SS & df & MS & $F$ & p \\
\hline Species $\times$ Habitat $\times$ Size & $10.65 \times 10^{5}$ & 16 & $66.56 \times 10^{3}$ & 116.37 & $<0.001$ \\
Species & $1.41 \times 10^{4}$ & 7 & $2.012 \times 10^{3}$ & 3.53 & $<0.001$ \\
Habitat & $1.04 \times 10^{4}$ & 1 & $10.42 \times 10^{3}$ & 18.22 & $<0.001$ \\
Species $\times$ Habitat & $2.19 \times 10^{4}$ & 7 & $3.13 \times 10^{3}$ & 5.48 & $<0.001$ \\
Error & $51.23 \times 10^{5}$ & 8956 & 572 & & \\
\hline
\end{tabular}

Siderastrea radians (Fig. 4). The population structure of these species was consistent, with no discernable influence of habitat type, suggesting that environmental factors contributed minimally to the (limited) variation observed in their population structure. The inland bay habitat therefore did not induce differences in population structure for all species equally and is thus not equally 'marginal' to all species. This is additionally supported by the observations that broadcastspawning species showed a larger difference in population structure between the 2 habitats than brooders and that only 3 species showed higher prevalence of partial mortality inside the inland bays: Montastraea annularis, S. radians and $S$. siderea. These species occurred in high densities inside the inland bays (Table 1) but they were also more susceptible to partial mortality in this habitat, which likely prevented these populations from developing to the extent of those at the reef sites. In this scenario, increased post settlement mortality rather than reduced larval supply is a dominant structuring factor for populations of these species residing in inland bays (for similar findings in the Pacific, see: Van Woesik \& Done 1997).

Increased partial mortality in Montastraea annularis in response to natural marginal conditions (i.e. storms, poor water quality) has been observed in various locations throughout the Caribbean (Bythell et al. 1993, Ginsburg et al. 2001) suggesting that this dominant Caribbean reef-building species can be regarded as a reliable, region-wide indicator of recent disturbance events.

Overall coral colony density was, on average, 12 times lower in inland bays than on the nearby reef sites, due to the fact that all species, with the exception of Favia fragum, occurred in lower densities inside the inland bays (Table 1). The difference in density between inland bays and reef sites was particularly large for broadcasting species. This contrasts with the small differences in density between habitat types of the brooders, especially for the most common brooding species, F. fragum and Siderastrea radians (Table 1). Populations of broadcasting species in inland bays are likely limited in larval supply since the populations serving as larval sources (inside the bay) are poorly developed and larval supply from the nearby reef is hindered by (1) reduced circulation inside bay due to low tidal fluctuations and (2) limited connection to the populations on the fringing reef. In contrast, brooding species share several characteristics that facilitate population establishment and maintenance inside the inland bays. First, species become reproductive at small sizes and have long reproductive periods, which makes recruitment less sensitive to temporal variation in environmental conditions (Szmant-Froelich et al. 1985, Soong 1991, McGuire 1998, Vermeij 2005). Second, brooding species typically show short dispersal distances on ecological timescales (Ayre \& Hughes 2000). Third, brooding species have large planulae, which reduces post-settlement mortality risks (Richmond 1988). These characteristics favor brooding species over broadcasting species to establish and maintain populations under suboptimal conditions, such as inside inland bays.

Recruitment limitation, slower growth and higher mortality probabilities likely occur synergistically in marginal habitats but can also affect community structure independently (Van Woesik et al. 1999). At present it is unclear which characteristic of the inland bay environment contributed most to the different structure of the coral communities it harbors. A processbased approach that considers structuring mechanisms within each habitat type (e.g. differences in circulation, sedimentation) would only address current environmental conditions and not necessarily those in the past, under which most of the colonies observed in this study settled and grew. Hence, the size-frequency distributions in this study should be regarded as a timeintegrated outcome of a species' population dynamics in 2 different environments, combining recent recruits as well as larger (i.e. older) colonies that have survived till present day. Lower density and an underrepresentation of colonies in larger size classes favor reduced larval supply and higher probabilities for total colony mortality or slower growth rates as most parsimonious explanations for the patterns observed in inland bay coral communities. These suggestions are consistent with earlier findings for Curaçao inland bays (Debrot et al. 1998), but also for a variety of other reef systems worldwide that can be regarded as 'marginal' reef communities (e.g. Kleypas 1996, van Woesik \& Done 1997, van Woesik et al. 1999, Ginsburg et al. 2001). In the present study, we built on this information by providing the means by which naturally and anthropogenically disturbed reef communities can be recog- 
nized for several common Caribbean coral species. For an elegant overview of other characteristics believed to characterize anthropogenically disturbed reefs, see Van Woesik \& Done (1997).

\section{CONCLUSIONS}

The present study found structural differences between coral communities in inland bay and reef habitats, and showed that such differences largely depended on the reproductive mode of the coral species. In comparison to broadcasting species, brooders are relatively more common in inland bays, most likely because under suboptimal conditions their reproductive strategy ensures a higher local supply of recruits through time. In inland bays, broadcasting species show a general underrepresention of large colonies, smaller colony size and lower density and size variation. None of the brooding species showed similar responses. Coral species population structures in inland bays, notionally referred to as natural 'marginal' environments, are structurally different from those in degraded reef communities. Because the latter can be considered 'marginal' as well, we propose that colony size-frequency information can be used to better characterize a locality's marginal nature by distinguishing between underlying natural and anthropogenic causative factors.

Acknowledgements. We thank the CARMABI foundation and Gerard Nieuwland for logistical support. The research was partially funded through a PRODEP grant (European Union) to P.R.F. and R.I.R.J. We thank M. Dailer, C. Birkeland and 3 anonymous reviewers for their constructive comments on an earlier version of the manuscript.

\section{LITERATURE CITED}

Ayre DJ, Hughes TP (2000) Genotypic diversity and geneflow in brooding and spawning corals along the Great Barrier Reef, Australia. Evolution 54:1590-1605

Bak RPM, Meesters EH (1998) Coral population structure: the hidden information of colony size-frequency distributions. Mar Ecol Prog Ser 162:301-306

Bak RPM, Meesters EH (1999) Population structure as a response of coral communities to global change. Am Zool 39:56-65

Bak RPM, Meesters EH (2003) Acclimatization/adaptation of coral reefs in a marginal environment. Proc 9th Int Coral Reef Symp I:265-272

Bythell JC, Bythell M, Gladfelter EH (1993) Initial results of a long-term coral reef monitoring program: impact of hurricane Hugo at Buck Island Reef National Monument, St. Croix, U.S. Virgin Islands. J Exp Mar Biol Ecol 172: 171-183

Debrot AO, Kuenen MMCE, Dekker K (1998) Recent declines in the coral fauna of the Spaanse Water, Curaçao, Netherlands Antilles. Bull Mar Sci 63:571-580
De Buisonjé PH (1974) Neogene and Quaternary geology of Aruba, Curaçao and Bonaire. Publ Found Sci Res Surinam Neth Antilles 78:1-293

De Graaf M, Geertjes GJ, Videler JJ (1999) Observations on spawning of scleractinian corals and other invertebrates on the reefs of Bonaire (Netherlands Antilles, Caribbean). Bull Mar Sci 64:189-194

Ginsburg RN, Eberhard G, Kiene WE (2001) Partial mortality of massive reef-building corals: an index of patch reef condition, Florida reef tract. Bull Mar Sci 69:1149-1173

Harrison PL, Wallace CC (1990) Reproducton, dispersal and recruitment of scleractinian corals. In: Dubinsky Z (ed) Ecosystems of the world 25. Coral reefs. Elsevier, Amsterdam, p 133-207

Hughes TP (1984) Population dynamics based on individual size rather than age: a general model with a reef coral example. Am Nat 123:778-795

Hughes TP, Connell JH (1999) Multiple stressors on coral reefs: a long-term perspective. Limnol Oceanogr 44: 932-940

Jackson JBC (1991) Adaptation and diversity of reef corals. BioScience 41:475-482

Kleypas JA (1996) Coral reef development under naturally turbid conditions: fringing reefs near Broad Sound, Australia. Coral Reefs 15:153-167

Klosowska B (2003) Late Holocene embayment and salina record of Curacao (Dutch Antilles): criteria to monitor environmental change and biodiversity. PhD dissertation, Free University of Amsterdam

Knowlton N (2001) The future of coral reefs. Proc Natl Acad Sci 98:5419-5425

Lesser MP, Mazel C, Phinney D, Yentsch CS (2000) Light absorption and utilization by colonies of the congeneric hermatypic corals Montastraea faveolata and Montastraea cavernosa. Limnol Oceanogr 45:76-86

McGuire MP (1998) Timing of larval release by Porites astreoides in the northern Florida Keys. Coral Reefs 17:369-375

Meesters EH, Wesseling I, Bak RPM (1997) Coral colony tissue damage in six species of reef-building corals: partial mortality in relation with depth and surface area. J Sea Res 37:131-144

Meesters EH, Hilterman M, Kardinaal E, Keetman M, Vries MD, Bak RPM (2001) Colony size-frequency distributions of scleractinian coral populations: spatial and interspecific variation. Mar Ecol Prog Ser 209:43-54

Meesters EH, Nieuwland G, Duineveld GCA, Kok A, Bak RPM (2002) RNA/DNA ratios of scleractinian corals suggest acclimatisation/adaptation in relation to light gradients and turbidity regimes. Mar Ecol Prog Ser 227: 233-239

Nugues MM, Roberts CM (2003) Coral mortality and interaction with algae in relation to sedimentation. Coral Reefs 22:507-516

Perry CT, Larcombe P (2003) Marginal and non-reef-building coral environments. Coral Reefs 22:427-432

Porter JW (1976) Autotrophy, heterotrophy, and resource partitioning in Caribbean reef-building corals. Am Nat 110:731-742

Richmond RH (1988) Competency and dispersal potential of planula larvae of a spawning versus a brooding coral. Proc 6th Int Coral Reef Symp 2:827-832

Roos PJ (1970) The shallow-water stony corals of the Netherlands Antilles. Stud Fauna Curaçao Other Caribb Isl $37: 1-108$

Rylaarsdam KW (1983) Life histories and abundance patterns of colonial corals on Jamaican reefs. Mar Ecol Prog Ser 13: $249-260$ 
Schleyer MH, Celliers L (2003) Coral dominance at the reefsediment interface in marginal coral communities at Sodwana Bay, South Africa. Mar Freshw Res 54:967 - 972

Sebens KP, Johnson AS (1991) Effects of water movement on prey capture and distribution of reef corals. Hydrobiologia 226:91-101

Smith SR (1992) Patterns of coral recruitment and postsettlement mortality on Bermuda's reefs: comparisons to Caribbean and Pacific reefs. Am Zool 32:663-673

Soong K (1991) Sexual reproductive patterns of shallowwater reef corals in Panama. Bull Mar Sci 49:832-846

Soong K (1993) Colony size as a species character in massive reef corals. Coral Reefs 12:77-83

Szmant AM (1986) Reproductive ecology of Caribbean reef corals. Coral Reefs 5:43-53

Szmant-Froelich AM, Riggs L, Reutter M (1985) Sexual reproduction of Favia fragum (Esper): lunar patterns of gametogenesis, embryogenesis and planulation in Puerto Rico. Bull Mar Sci 37:880-892

Van Duyl FC (1985) Atlas of the living reefs of Curaçao and Bonaire, Netherlands Antilles. Publ Found Sci Res Surinam Neth Antilles 117:1-38

Van Woesik R, Done TJ (1997) Coral communities and reef

Editorial responsibility: Charles Birkeland (Contributing

Editor), Honolulu, Hawaii, USA growth in the southern Great Barrier Reef. Coral Reefs 16: 103-115

Van Woesik R, Tomascik T, Blake S (1999) Coral assemblages and physico-chemical characteristics of the Whitsunday Islands: evidence of recent community changes. Mar Freshw Res 50:427-440

Vermeij MJA (2005) Substrate composition and adult distribution determine recruitment patterns in a Caribbean brooding coral. Mar Ecol Prog Ser 295:123-133

Vermeij MJA (2006) Early life-history dynamics of Caribbean coral species on artificial reefs: the importance of competition, growth and variation in life-history strategy. Coral Reefs 25:59-71

Vermeij MJA, Bak RPM (2003a) Species-specific population structure of closely related coral morphospecies along a depth gradient $(5-60 \mathrm{~m})$ over a Caribbean reef slope. Bull Mar Sci 73:725-744

Vermeij MJA, Bak RPM (2003b) Inferring demographic processes from population size structure in corals. Proc 9th Int Coral Reef Symp 1:589-594

Wagenaar Hummelinck P (1977) Marine localities: studies on the fauna of Curaçao and other Caribbean islands. Publ Found Sci Res Surinam Neth Antilles 51:15-68

Submitted: February 18, 2006; Accepted: May 18, 2007 Proofs received from author(s): November 14, 2007 